\title{
IN MEMORIAM: PROFESSOR LYDIA BAUMBACH
}

The death of Lydia Baumbach in Groote Schuur Hospital on 9 February 1991 came as a shock to all who knew her, and especially to those who had heard her deliver a paper at the biennial conference of the Classical Association of South Africa at the University of Cape Town in January. She was in good spirits and to all appearances in good health, although we knew that she was going to see a specialist immediately after her paper to fix a date for an orthopedic operation.

It is not surprising that she made her career in the study of languages, for she grew up in a mix of three linguistic traditions. The influence of diverse cultural traditions determined not only her interest in philology. Her family is linked with the foundation of the Rhenish Mission in Stellenbosch, and this strand in her background explains why she maintained a special association with the Rhenish School, why she recognized a vocation to serve as a lay preacher in the Presbyterian Church, and why her academic studies reflected the Germanic tradition of classical scholarship. Growing up in Stellenbosch and studying and then lecturing at the University of Stellenbosch, Lydia developed in the tradition of Afrikanerdom, but while this gave her an understanding of the language and lore of Afrikaners it did not mean that she accepted the apartheid ideology: like many liberal Afrikaners she used her position in that society to argue for a better way and to fight for social justice when she was in a position to make a positive contribution. She went as a graduate to Cambridge and spent most of her working life in the English-medium universities of Rhodes and Cape Town, and her acquaintances abroad no doubt thought of Lydia as an English-speaking South African with a Germanic name.

When Lydia served on the staff of Rhodes University in Grahamstown she was spoken of as the Greek philologist who had made her name with the work she had done with John Chadwick on the language of the Linear B scripts. She had studied in Cambridge in the heady days when the decipherment of Linear B presented exciting new prospects for historians, archaeologists and philologists, and the irreverent could revel in the caustic wit of the devil's advocates. Lydia was too sound and conservative a scholar to be lured into following an insubstantial chimaera. Ventris and Chadwick were right and Lydia was set on an academic career centred on research into early Greek and the historical value of the Linear B texts.

She moved from Grahamstown to the Department of Greek at the University of Pretoria, and there in 1964 she shocked the more conservative fathers of the Classical Association by giving a public lecture on the U.P. campus in English. The size of her audience and the popularity of her introduction to Linear B brought new life to the Transvaal Branch of C.A.S.A. Unfortunately her Head of Department was less progressive as the patriarch of the department than he was in national politics, and Lydia was not one to keep quiet when she believed that she was right. She was also troubled by what she saw as discrimination by gender. It would not be fair to claim that the University of Cape Town set a shining example in this regard, but, if U.C.T. was not exactly free of prejudice, it was at least closer to Stellenbosch, and in 1965 Lydia was encouraged to accept a senior lectureship in Cape Town. She subsequently became a full professor in 1977, and took over the headship of the Department in 1982, retiring at the end of 1987. 
Her special contribution to the department was in the field of Latin and Greek philology, to which subject she took an holistic approach, so that whether her students were taking Latin or Greek the syllabus was bound to start not too far from Linear B, include some Plautine Latin and touch on modern derivatives. She was rewarded with two students producing M.A. theses on Linear B topics, and she launched one of them on a Ph.D. project which is still in progress. Her own research resulted in the publication of "Mycenaean Greek Vocabulary II" in Glotta xlix, 1979, and the two volumes entitled Studies in Mycenaean inscriptions and dialect (1968 and 1986), which offered an analytical survey of every scholarly publication on the Linear B texts from 1953 to 1974. In addition she published a series of conference papers: indeed the list of her papers reads like a catalogue of conferences on Mycenaean studies.

Lydia always emphasized the primacy of language studies while actively promoting the development of courses in Ancient History and classical literature in translation, and she was vindicated in that U.C.T. both managed to mount three undergraduate courses in Ancient History leading to an Honours degree and postgraduate study and to increase the number of students in the language courses. She also played a role in developing a three year programme in Greek and Roman literature and thought in translation. She could claim the credit for having established courses on legal texts in Latin at senior undergraduate and postgraduate levels.

Her concern for students can be vouched for by generations of students who knew her as a lecturer or as a Student Adviser, and also by the number of young academics who were encouraged by her to make a career in teaching and research.

She built up quite a following as a public lecturer. The last time she offered a course at the Summer School organised by the Extra-Mural Studies Board she drew an audience of more than 300 at each lecture. Her popularity as a speaker on Greek sites and antiquities led to her leading a tour to Greece in 1976 with a party of about 70 . Such are the social dynamics of tour groups that when Lydia slipped off one morning at dawn in Heracleion to swap a blouse she had bought the previous day she suddenly became aware of a crocodile of 35 pairs of Kapenaars running to catch her up. After this strenuous but highly successful exercise in DIY tour organising Lydia decided to leave it to the professionals, and became a regular guest lecturer for Swan Hellenic Tours, which had the indirect benefit of increasing the repertoire of lectures which she could offer to students on the classical sites.

She was too honest and had too rich a sense of the ridiculous to conceal her failings. Thus the tale may not be entirely apocryphal that one very hot Cape afternoon when she was taking a class on Greek philology she woke her student up by talking in her sleep. And many an early morning lecture began a little late because she dozed through the brittle call of "Rondebosch Station, next stop Rosebank".

But she was anything but dormant when the vital interests of the Department were at stake: she campaigned with vigour against a plan to split up the Classics Department after she retired, and members of the Classical Association will remember the determined way in which she pressed the case for retaining Latin as a statutory requirement in the training of aspirant advocates. She was also a forceful Chief Moderator for Latin for the Joint Matriculation Board and made her contribution to the strengthening of Latin teaching in the schools. It was a fitting climax to her time in the Classical Association that she served as its Chairperson in the period 1983-1985. 
In retirement she moved to MacGregor, revitalised the local literary society, became an entrepreneur, found new research interests - but that is another story.

Classics in South Africa is the poorer for her passing.

John Atkinson, University of Cape Town

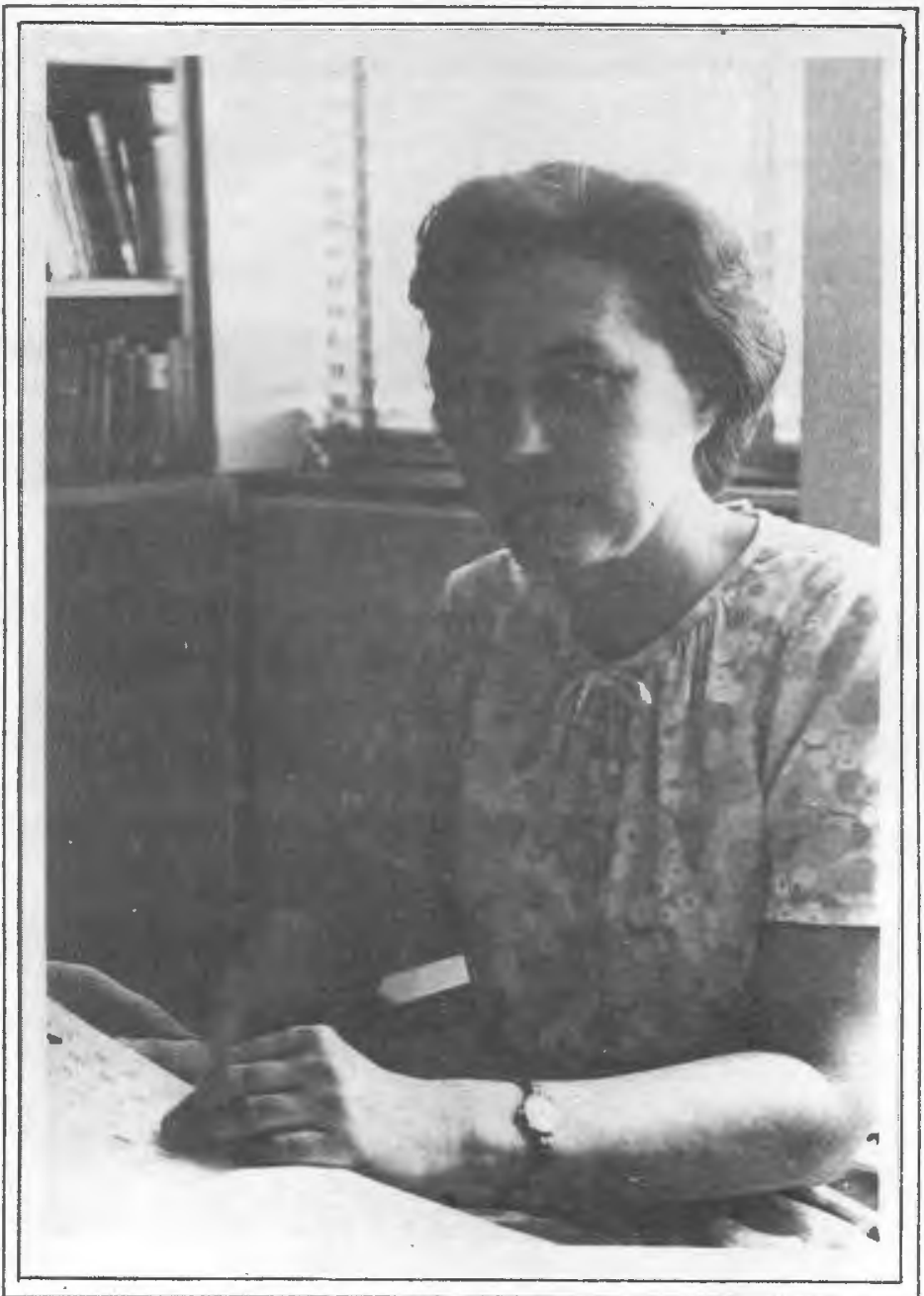

